\title{
Analysis of insomnia in those over 60 year of age
}

\author{
WERONIKA WOLIŃSKAA-F, IWONA EWA PAWLAK'B, D, BOŻENA MROCZEKA, D
}

Department of Human Sciences in Medicine, Pomeranian Medical University in Szczecin

A - Study Design, B - Data Collection, C - Statistical Analysis, D - Data Interpretation, E - Manuscript Preparation,

$\mathbf{F}$ - Literature Search, G - Funds Collection

Summary Background. Insomnia means an absolute lack of sleep; however, in reality, it is a more complex phenomenon. Insomnia is characterized by an insufficient quantity or quality of sleep. For diagnosis of insomnia, it is crucial to find out about the patient's subjective feelings. Loneliness is a phenomenon that people experience in an individual way - subjectively. The problems with sleep intensify with age, which can consequently cause depression. Depression is conducive to loneliness, both as a temporary feeling as well as a continual feeling of loneliness and exclusion.

Objectives. The aim of this research was to the evaluation of frequency of insomnia among individuals over 60 years of age students of the University of the Third Age in Stargard.

Material and methods. The research was conducted among 131 individuals aged 60 years and over, including $72.51 \%(n=$ 95) females and $27.48 \%(n=36)$ males. The mean age was $68.12 \pm 6.63$. The survey was used with elements of the Athens Insomnia Scale (AIS), Insomnia Severity Index (ISI), Beck Depression Inventory and the author's proprietary questionnaire with socio-economic data.

Results. Insomnia was observed among $27.48 \%(n=36)$ of the respondents surveyed with AIS. More than $25 \%(n=33)$ of respondents scored on the borderline for diagnosis of insomnia. The results obtained by combining the Beck Depression Inventory with Athens Insomnia Scale show a statistically significant relationship between insomnia and depression $(p=0.0001)$.

Conclusions. Insomnia is present in more than a quarter of respondents among persons above 60 years of age, being students of the University of the Third Age in Stargard.

Key words: depression, insomnia, Beck Depression Inventory, Athens Insomnia Scale (AIS), Insomnia Severity Index (ISI).

Wolińska W, Pawlak IE, Mroczek B. Analysis of insomnia in those over 60 year of age. Fam Med Prim Care Rev 2016; 18(4): 482-485, doi: 10.5114/fmpcr.2016.63707.

\section{Background}

Insomnia is a complex phenomenon manifested by an insufficient amount of sleep, which is necessary for the human organism to regenerate and function properly during the day [1]. In accordance with the International Classification of Disorders-10 (ICD-10), insomnia is characterized by an inadequate amount and worse quality of sleep. It is diagnosed if a patient experiences the nuisance of sleeplessness at least three times a week for one month [2]. The International Classification of Sleep Disorders-2 (ICSD-2) organizes problems with sleep into eight categories, namely insomnias - sleep-related breathing disorders - hypersomnias of a central origin - circadian rhythm sleep disorders - parasomnias - sleep-related movement disorders - isolated symptoms, apparent normal variants and unresolved issues - and other sleep disorders [3]. There are many factors that can contribute to developing insomnia, among them age, concomitant chronic diseases, depression and other mental health conditions, traumatic events and, last but not least, noncompliance with the fundamental principles of sleep hygiene, such as keeping to a regular sleep schedule and avoiding caffeinated drinks and heavy meals before bedtime [4-7]. Therefore, to make a correct diagnosis of insomnia, self-report sleep-related questionnaires should be employed. Individuals over 60 show a greater tendency to sleep disorders, especially insomnia. Studies show that this problem affects more than half of this age group [7-10]. Those elderly who battle against chronic insomnia may also face additional consequences from the lack of sleep. Insomnia hinders daily functioning, reduces concentration and decreases physical efficiency, leading, as a result, to a decline in quality of life [11]. Age and concomitant chronic diseases, including depression, contribute to a feeling of loneliness and worsening of mental health [12]. In the group of depressive patients, over $65 \%$ of individuals older than 60 have insomnia [13]. Both depression and insomnia create favorable conditions for developing feelings of loneliness and social exclusion [14].

\section{Objectives}

The aim of this study was to analyze the incidence of insomnia among members of the University of the Third Age in Stargard over 60 years of age.

\section{Material and methods}

Respondents were randomly recruited from members of the University of the Third Age in Stargard, due to the fact that this group has not yet been analyzed with regard to sleep disturbances. The criterion for inclusion to the study was being at least 60 years of age. The study involved 131 subjects from Stargard in the West Pomeranian Voivodeship, including 95 females $(72.52 \%)$ and 36 males (27.48\%). The participants were 60-85 years of age (mean age: $68.12 \pm$ 6.63) (Table 1). Some $63.35 \%(n=83)$ of them were married, $31.29 \%(n=41)$ were widowed, and $5.34 \%(n=7)$ were single. The research instruments used in this surveybased study were: the Athens Insomnia Scale (AIS), the Insomnia Severity Index (ISI), the Beck Depression Inventory (BDI) and the authors' questionnaire concerning socio- 
economic data. The AIS consists of eight insomnia-related questions, each answered on a four-point scale and scored $0-3$. The AIS total scores are interpreted as follows: $<5$ points - no insomnia, 6-10 points - borderline insomnia, $>10$ points - insomnia. The ISI has seven questions about insomnia severity, each answer being scored on a scale value of $0-4$. The cut-off scores for the ISI are: $0-7-$ no clinically significant insomnia, 8-14 - subthreshold insomnia, 15-21 - clinical insomnia of moderate severity, 22-28 - clinical severe insomnia. The BDI is a 21 -item self-report measure of depressive symptoms, each being scored $0-3$. The scoring is as follows: $0-11$ points - no depression, $12-26$ points - mild depression, 27-49 points - moderate depression, and 50-63 points - severe depression.

Pearson's chi-square test for independence was applied. The level of statistical significance was set at $p \leq 0.05$. Statistical analysis was performed using PQStat software and an Excel spreadsheet.

\begin{tabular}{|l|l|}
\hline \multicolumn{2}{|l|}{ Table 1. Characteristics of the study sample } \\
\hline Variable & $n(\%)$ \\
\hline Number of respondents & $131(100 \%)$ \\
\hline $\begin{array}{l}\text { Sex: } \\
\text { female } \\
\text { male }\end{array}$ & $95(72.51 \%)$ \\
\hline Age' [years] & $36(27.48 \%)$ \\
\hline & $\chi=68.12 \pm 6.63$ \\
\hline Marital status: & Min. 60 years \\
married & Max. 82 years \\
widowed & \\
single & $83(63.35 \%)$ \\
\hline Education: & $41(31.29 \%)$ \\
primary & $7(5.34 \%)$ \\
vocational & \\
secondary & $9(6.87 \%)$ \\
third level & $16(12.21 \%)$ \\
\hline
\end{tabular}

${ }^{1}$ Arithmetic mean $\pm \mathrm{SD}$ (minimum and maximum ranges).

\section{Results}

$27.48 \%$ ( $n=36$ ) of the respondents had insomnia, and one fourth $(25.19 \%, n=33)$ obtained results suggesting a risk of insomnia (Figure 1).

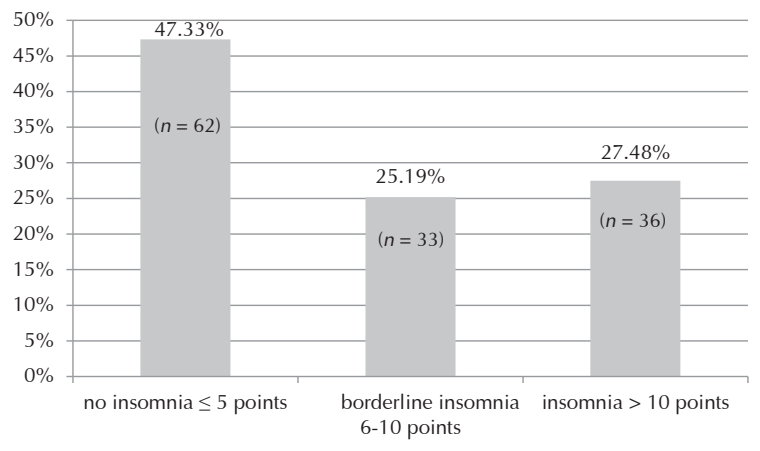

Figure 1. Incidences of insomnia according to the AIS

Insomnia was observed in $31.58 \%(n=30)$ of females and $16.66 \%(n=6)$ of males in the study. Additionally, $25.26 \%(n=24)$ of females had borderline insomnia (Table 2). There were no statistically significant relationships between insomnia and such variables as age and sex. Insomnia was more common among married respondents (20.48\%; $n=17$ ).

Statistical analysis was performed to determine relationships between selected socio-demographic variables and the severity of insomnia according to the ISI (Table 3 ). The severity of insomnia was proven to be statistically significantly related to the respondents' age $\left(\mathrm{Chi}^{2}=96.18\right.$; $p=0.016)$ and marital status. Subthreshold and moderate insomnia were more common among the widowed $\left(\mathrm{Chi}^{2}=\right.$ 19.067; $p=0.004)$.

Out of $36(27.48 \%)$ subjects with insomnia, 18 (50\%) had mild depressive symptoms, and 7 (19.44\%) had moderate depressive symptoms. Insomnia was statistically significantly related to the severity of depressive symptoms $\left(\mathrm{Chi}^{2}=\right.$ 39.799; $p=0.0001$ ) (Table 4).

\begin{tabular}{|c|c|c|c|c|c|}
\hline \multirow{2}{*}{ Variable } & \multicolumn{3}{|c|}{ Athens Insomnia Scale } & \multirow[t]{2}{*}{$\mathrm{Chi}^{2}$} & \multirow[t]{2}{*}{$p$} \\
\hline & $\begin{array}{l}\text { no insomnia } \\
n(\%)\end{array}$ & $\begin{array}{l}\text { borderline insomnia } \\
n(\%)\end{array}$ & $\begin{array}{l}\text { insomnia } \\
n(\%)\end{array}$ & & \\
\hline \multicolumn{6}{|l|}{ Sex } \\
\hline Female & $41(43.16 \%)$ & $24(25.26 \%)$ & $30(31.58 \%)$ & \multirow[t]{2}{*}{3.386} & \multirow[t]{2}{*}{0.184} \\
\hline Male & $21(58.33 \%)$ & $9(25 \%)$ & $6(16.66 \%)$ & & \\
\hline \multicolumn{6}{|l|}{ Age } \\
\hline 60-69 years & $44(54.32 \%)$ & $20(24.69 \%)$ & $17(20.99 \%)$ & \multirow[t]{3}{*}{42.155} & \multirow[t]{3}{*}{0.633} \\
\hline 70-79 years & $15(38.46 \%)$ & $10(25.65 \%)$ & $14(35.89 \%)$ & & \\
\hline 80 years or more & $3(27.27 \%)$ & $3(27.27 \%)$ & $5(45.45 \%)$ & & \\
\hline \multicolumn{6}{|l|}{ Marital status } \\
\hline Single & $2(28.57 \%)$ & $2(28.57 \%)$ & $3(42.86 \%)$ & \multirow[t]{3}{*}{8.696} & \multirow[t]{3}{*}{0.069} \\
\hline Married & $47(56.62 \%)$ & $19(22.89 \%)$ & $17(20.48 \%)$ & & \\
\hline Widowed & $13(31.70 \%)$ & $12(29.27 \%)$ & $16(39.02 \%)$ & & \\
\hline
\end{tabular}




\begin{tabular}{|c|c|c|c|c|c|c|}
\hline \multirow[t]{2}{*}{ Variable } & \multicolumn{4}{|c|}{ Insomnia Severity Index (ISI) } & \multirow[t]{2}{*}{$\mathrm{Chi}^{2}$} & \multirow[t]{2}{*}{$p$} \\
\hline & $\begin{array}{l}\text { no insomnia } \\
n(\%)\end{array}$ & $\begin{array}{l}\text { subthreshold } \\
\text { insomnia } n(\%)\end{array}$ & $\begin{array}{l}\text { moderate insomnia } \\
n(\%)\end{array}$ & $\begin{array}{l}\text { severe insomnia } \\
n(\%)\end{array}$ & & \\
\hline \multicolumn{7}{|l|}{ Sex } \\
\hline Female & $40(42.10 \%)$ & $44(46.31 \%)$ & $9(9.47 \%)$ & $2(2.10 \%)$ & \multirow[t]{2}{*}{4.997} & \multirow[t]{2}{*}{0.171} \\
\hline Male & $22(61.11 \%)$ & $10(27.77 \%)$ & $4(11.11 \%)$ & - & & \\
\hline \multicolumn{7}{|l|}{ Age } \\
\hline $60-69$ years & $39(48.15 \%)$ & $37(45.68 \%)$ & $5(6.17 \%)$ & - & \multirow[t]{3}{*}{96.18} & \multirow[t]{3}{*}{0.016} \\
\hline 70-79 years & $18(46.15 \%)$ & $14(35.90 \%)$ & $6(15.38 \%)$ & $1(2.56 \%)$ & & \\
\hline 80 years or more & $5(45.45 \%)$ & $3(27.27 \%)$ & $2(18.18 \%)$ & $1(9.09 \%)$ & & \\
\hline \multicolumn{7}{|l|}{ Marital status } \\
\hline Single & $1(14.28 \%)$ & $5(71.42 \%)$ & $1(14.28 \%)$ & - & \multirow[t]{3}{*}{19.067} & \multirow[t]{3}{*}{0.004} \\
\hline Married & $51(61.44 \%)$ & $24(28.91 \%)$ & $7(8.43 \%)$ & $1(1.20 \%)$ & & \\
\hline Widowed & $10(24.39 \%)$ & $25(60.97 \%)$ & $5(12.19 \%)$ & $1(2.43 \%)$ & & \\
\hline
\end{tabular}

\begin{tabular}{|c|c|c|c|c|c|c|}
\hline \multirow[t]{2}{*}{ Questionnaire } & \multicolumn{4}{|c|}{ Severity of depressive symptoms } & \multirow[t]{2}{*}{$\mathrm{Chi}^{2}$} & \multirow[t]{2}{*}{$p$} \\
\hline & none & mild & moderate & severe & & \\
\hline \multicolumn{7}{|l|}{ AIS* } \\
\hline No insomnia & $53(85.48 \%)$ & $9(14.52 \%)$ & - & - & \multirow[t]{3}{*}{39.799} & \multirow[t]{3}{*}{0.0001} \\
\hline Borderline insomnia & $20(60.60 \%)$ & $13(39.39 \%)$ & - & - & & \\
\hline Insomnia & $11(30.55 \%)$ & $18(50 \%)$ & $7(19.44 \%)$ & - & & \\
\hline
\end{tabular}

*AIS - Athens Insomnia Scale.

\section{Discussion}

Sleep is essential for a person's health and well-being. Its deficiency, accompanied by daytime impairment and distress attributed to sleep disturbances, may suggest insomnia. Since $30 \%$ of the world's population is burdened with chronic insomnia, it is regarded as a serious public health problem [15].

Our research conducted among members of the University of the Third Age in Stargard over 60 year of age demonstrated that about one third of them suffered from insomnia, and one fourth had borderline insomnia. Thus, we can say that insomnia is a problem which affects elderly people [16]. Similar results were reported by Ohayon [9] and Almeida and Pfaff [10].

We analyzed incidences of insomnia with regard to demographic data, such as sex, age and marital status. Insomnia and borderline insomnia were observed in the majority of females, and only $16.66 \%$ of males, which may have been associated with the fact that the number of females in the study was larger than the number of males. Pływaczewski et al. [17], Mroczek et al. [18] and Bidzan [19] provided evidence for insomnia being noticeably more common in individuals over 60 and females.

In our study, insomnia was statistically significantly related to depression. Sleep disorders, including early morning awakening and difficulties falling asleep, belong to characteristic symptoms of depression. Hence, insomnia can inten- sify depressive symptoms. Similar results were obtained by Siemiński et al. [20], who established statistically significant relationships between depression and problems with falling asleep and waking up too early among over 60 year olds.

We assumed that age is a determinant of the incidence and severity of insomnia; however, we did not find any statistically significant relationship between the age of the respondents and the presence of insomnia measured by the AIS. Nevertheless, this might have been caused by the small age differences within the study sample. This thesis seems to be supported by the outcomes of Szelenberger and Skalski, who claim that insomnia is two to three times more common in individuals over 65 [21].

\section{Limitation}

Other factors interfering with sleep, such as pressure, environmental stress factors, including noise and lifestyle, were not taken into account in our study.

\section{Conclusions}

1. Insomnia was noted in more than one fourth of our study sample consisting of over 60 year old members of the University of the Third Age in Stargard. In this group, mild and moderate depression was observed.

2. The severity of insomnia was proven to be related to age. Moderate and severe insomnia were more common among individuals aged 70 years or more. 


\section{References}

1. Szelenberger W, Jakitowicz J. Bezsenność - problem diagnostyczny i terapeutyczny. In: Szelenberger W, Nowicki Z, eds. Zaburzenia snu. Diagnostyka i leczenie, wybrane zagadnienia. Kraków: Wydawnictwo Komitet Redakcyjno-Wydawniczy Polskiego Towarzystwa Psychiatrycznego; 1999: 19-31.

2. World Health Organization. International Statistical Classsification of Diseases and Related Health problems. 10th Ed. rev. Geneva: World Health Organization; 1992.

3. International Classification of Sleep Disorders: Diagnostic and Coding Manual. 2. Westchester: American Academy of Sleep Medicine; 2005.

4. Prusiński A. Bezsenność i inne zaburzenia snu. Warszawa: Wydawnictwo Lekarskie PZWL; 2007: 12-43.

5. Bloom HG, Imram A, Alessi CA, et al. Evidence-based recommendations for the assessment and management of sleep disorders in older persons. J Am Geriatr Soc 2009; 57(5): 761-789.

6. National Institute of Mental Health. Consensus Development Conference: drugs and insomnia. The use of medications to promowe sleep. JAMA 1984; 251(18): 2410-2414.

7. Dudzińska M, Neć M, Zwolak A, et al. Bezsenność - istotny problem w codziennej praktyce lekarskiej - doniesienia wstępne. Fam Med Prim Care Rev 2015; 17(2): 90-93.

8. Nowicki Z, Grabowski K, Cubała WJ, et al. Rozpowszechnienie subiektywnej bezsenności w populacji polskiej. Psychiatr Pol 2016; 50(1): 165-173.

9. Ohayon MM. Epidemiology of insomnia: what we know and what we still need to learn? Sleep Med Rev 2002; 6(2): 97-111.

10. Almeida OP, Pfaff JJ. Sleep complaints among older general practice patients: association with depression. Br J Gen Pract 2005; 55(520): 864-866.

11. Jarczewska DŁ, Krztoń-Królewiecka A, Windak A. Pierwotne zaburzenia snu u osób w wieku podeszłym. Lek Rodz 2013; 18(6): 398-409.

12. Zielińska-Więczkowska H, Kędziora-Kornatowska K, Kornatowski T. Starość jako wyzwanie. Gerontol Pol 2008; 16(3): 131-136.

13. Ohayon MM, Roth T. What are the contributing factors for insomnia in the general population? J Psychosom Res 2001; 51(6): 745-755.

14. Agargun MY, Kara H, Solmaz M. Sleep disturbances and suicidental behavior in patients with major depression. J Clin Psychiatry 1997; 58(6): 249-251.

15. Buysse DJ, Germain A, Douglas E, et al. Efficacy of brief behavioral treatment for chronic insomnia in older adults. Arch Intern Med 2011; 171(10): 887-895.

16. Montgomery P, Shepard LD. Insomnia in older people. Rev Clin Gerontol 2010; 20(3): 205-218.

17. Pływaczewski R, Bednarek M, Jończak L, et al. Sleep - desordered breathing in a middle - aged and older Polish urban population. J Sleep Res 2008; 17(1): 73-81.

18. Mroczek B, Mazurek D, Rotter I, et al. Ocena występowania bezsenności wśród ludzi w wieku produkcyjnym. Fam Med Prim Care Rev 2009; 11(3): 428-429.

19. Bidzan L. Zaburzenia snu w wieku podeszłym. Geriatria 2011; 5(1): 34-40.

20. Siemiński M, Potocka M, Karwacka M, et al. Bezsenność i stosowanie leków nasennych wśród osób starszych przebywających w domach opieki. Sen 2006; 6(2): 54-57.

21. Szelenberger W, Skalski M. Epidemiologia zaburzeń snu w Polsce. Doniesienia wstępne. In: Szelenberger W, Nowicki Z, eds. Zaburzenia snu. Diagnostyka i leczenie, wybrane zagadnienia. Kraków: Wydawnictwo Komitet Redakcyjno-Wydawniczy Polskiego Towarzystwa Psychiatrycznego; 1999: 57-63.

Tables: 4

Figures: 1

References: 21

Received: 21.01.2016

Revised: 19.02.2016

Accepted: 23.03.2016

Address for correspondence:

Weronika Wolińska, MSc

Zakład Nauk Humanistycznych w Medycynie PUM

ul. Chłapowskiego 11

70-103 Szczecin

Polska

Tel.: +48 91 441-47-40

E-mail: weronika.wolinska@pum.edu.pl 